\title{
An Interpretation of Emily Dickinson's Nature Poems from the Ecocritical View
}

\author{
Zhang Guifang \\ Department of Humanity and Management. \\ Jiangxi Police Institute \\ Jiangxi, Nanchang \\ lmlmlml@163.com
}

\begin{abstract}
Emily Dickinson was a prominent American poet, whose poems could be divided into about nature, love, death, and religion. It is worth noting that the poems about nature occupy a rather part in number, over one third of all. In the context of ecological deterioration today, it is great significance realistically to reread Dickinson's nature poetry from a new angle, the perspective of eco-criticism, which not many people did before. Through the close reading of Dickinson's nature poems, the thesis attempts to explore the ecological consciousness hidden in Dickinson's natural poetry, which embodies in the harmony between nature and man, such as living poetically in harmonious nature, all the living in nature are equal and awe for nature. The aim of this thesis is to shed light on the appropriate attitude toward nature and toward themselves which human beings should take and inspire people's ecological consciousness to protect our degrading environment and keep our spirit innocent when facing the serious ecological crisis in nature as well as in spirit.
\end{abstract}

Keywords-Emily Dickinson; Nature poetry; Ecological consciousness; Harmony

\section{INTRODUCTION}

It is true that after the industrial revolution in Europe, science and technology have developed rapidly, and human society has made great strides in politics, economy, culture and other fields. However, it has become an undeniable fact that, to some degree, the so-called development has pushed people to destroy the ecological environment. "Development is a comfortable illness, but it is also an incurable disease. And it is because of the development that human beings are not able to see the disasters ahead". But it is ironic that we have no access to restrict our ambitions to domination, conquest and occupation. The global ecological crisis, which requires people to think more about our status in the nature and pose pressing challenges on our dignity and existence.

Historian Donald Worster maintains that humanities scholars have an important role to play in addressing these crises: "We are facing a global crisis today, not because of how ecosystems function but rather because of how our ethical systems function. Getting through the crisis requires understanding our impact on nature as precisely as possible, but even more, it requires understanding those ethical systems and using that understanding to reform them. Historians, along with literary scholars, anthropologists, and philosophers, cannot do the reforming, of course, but they can help with the understanding."'[1] Emily Dickinson, as one of most important American poets in American literature history, has great influences on readers of different generations, whose writings have been interpreted from a wide variety of perspectives, and her ecological consciousness elaborated in her natural poems has great significance to today's society.

\section{HARMONY BETWEEN MAN AND NATURE}

Since 1950s, Emily Dickinson had begun to seclude within her family's home, Amherst, Massachusetts, except for rare meetings with her relatives and friends, being an introverted and hermetic person, which provide her a close connection with nature. Nature phenomena, changes of seasons, heavenly bodies, animals, birds and insects, flowers of various kindsall these and many other subjects related to nature find their way into her poetry[2]. Closing reading Dickinson's nature poetry, what we experienced is more than a magnificent and meaningful nature, and what's more, ecological consciousness is inspired and the heavy responsibility to protect our environment is stimulated. The harmonious relationships between nature and humans are mirrored through three respects nature is human beings poetical dwelling, the sun shines upon all alike on the earth and awe for life or awe for nature.

\section{A. Dwelling Poetically in Nature}

"Full of merit, yet poetically, man

Dwells on this earth." [3]

Martin Heidegger, one of the theological source of deep ecology, while making a further explanation, places more emphasis on the "poetic" nature of dwelling. He points out that poetry builds up the very nature of dwelling; that poetry and dwelling not only do not exclude each other, on the contrary, they belong together, each calling for the other.

Although Dickinson didn't seclude in the forest and made a cabin to live like David Thoreau, the well-known ecologist, she lived a life filled with imagination and created her own shelter in the accustomed circumstance. The place is Amherst of Massachusetts, or nature. She leaded a simple and poetical life in Amherst most of her life. Just like she said in Poem 303: "The soul selects her own society, -- Then --shuts the door --To 
her divine majority --Present no more." Her own society is the true inner world in her heart, which is externalized in the nature. "Some keep the Sabbath going to church--- I keep it staying at home--- With a bobolink for a chorister-And an orchard for a dome." (Poem, 324) It is apparent that Dickinson took "orchard" as her dome unlike some "going to church" because Nature is "Heaven" and "Nature is harmony" in her poem 668:

"Nature" is what we see -

The Hill -- the Afternoon --

Squirrel -- Eclipse -- the Bumble bee --

Nay -- Nature is Heaven --

Nature is what we hear --

The Bobolink -- the Sea --

Thunder -- the Cricket --

Nay -- Nature is Harmony --

Nature is what we know --

Yet have no art to say --

So impotent Our Wisdom is

To her Simplicity. (Poem, 668)

This poem is Dickinson's definition of nature. She used things people were familiar with to describe the beautiful scenery in nature. The Hill, squirrels the "Bumble bee" and the sea, all things are concordant. "what we see" is that "Nature is Heaven", where animals and plants live freely. The word "Heaven" makes us think of Eden which is the first home of Adam and Eve. It is a primitive but harmonious dwelling with no desire, no any trace of modern industry. "what we hear" is that "Nature is Harmony" where animals can shout out as they like. The word "Harmony" not only means the affinity between creatures and sound in nature, but also nature and the human beings. Such an indication of topic is in agreement with Emerson's view of nature that man can get inspirations about morality and wisdom from it, and nature and human race can coexist harmoniously. Nature is the harmonious coexistence of all the things known by our senses and intuition, and a dwelling place for so many fascinated creatures, emotions and vistas.

Dickinson believed that everything in nature could get along well and lived harmoniously, which was perfect and beautiful. Just as is said by Emerson in his essay "Nature": although everything in nature appears differently, what they appear on earth are same and simple---perfection and harmony, that is, the beauty. From the harmonious image of nature in Dickinson's eyes, the ecological consciousness is felt clearly: Everything in nature is closely and harmoniously related with each other. According to deep ecology, in union with nature rather than in center of nature, the ecological "self" means organic wholeness. Only by identification with nature and being in harmony with nature can humans live an ecological life that benefits the well-being of the whole ecosystem

In another poem, the poet uses her own experience to illustrate her keen desire to return to nature and blend in with nature.
The Bee is not afraid of me.

I know the Butterfly.

The pretty people in the Woods

Receive me cordially --

The Brooks laugh louder when I come --

The Breezes madder play;

Wherefore mine eye thy silver mists,

Wherefore, Oh Summer's Day? (Poem, 53)

"Returning to nature" or "blending in with nature" is a constant theme and an unchanged dream of all, eco-literatures. Dickinson compares the bee to a friend, and she marvels at the butterfly's elegance. On the other hand, nature seems to welcome the poet's visit, for "the brooks laugh louder" and "the breezes play more madly". This poem reveals the poet's hope of being one part of nature again. She wants to be the same as bees and butterflies, and all are the appreciators and beneficiaries of nature. Notice how in the poem she gives nature its own personality--hospitable, easygoing and lovely. Nature is not alone, for it has a cordial friend, which is called as human beings.

As a poet who loved and infatuated with nature, Dickinson was deeply influenced by the idea of "blending in with nature". The fact that every being lived freely and easily in nature attracted Dickinson so strongly that she was eager to became a rose and blend in with nature. Such primitivism, defined by Glen. A. Love, is "a returen to earth, Thoreau-like, to confront the essential facts of life and reduce life to its most elemental terms"

\section{B. The Sun Shines upon All alike on the Earth}

Anthropocentricism regards human beings as the center of the universe. In terms of its theory, all the creatures in nature are divided into "good" and "harm", "beneficial insects" and "destructive insects". The division is completely with human beings' interests as criterion and creatures in nature are not worth a half penny. In the light of ecological ethics, one of the philosophical bases of ecocriticism, however, all creatures in nature are intrinsically equal, and they do not take human beings' benefits as their terminal interests of their existence but have their own purposes of breeding, development, prosperity and death and exist for their own.

The consciousness of equality between nature and human beings displays in Dickinson's poems everywhere. She took the butterfly as the "pretty people of in the woods". She called the rat, at which people turn up nose, "the concisest tenant" and said "Neither decree / Probits him, /Lawful as / Equilibrium". What impresses us most may be Dickinson's poem 790:

Nature, the gentlest mother,

Impatient of no child,

The feeblest of the waywardest,

Her admonition mild. 
When all the children sleep

She turns as long away

As will suffice to light her lamps;

Then, bending from the sky,

With infinite affection

And infiniter care,

Her golden finger on her lip,

Will silence everywhere. (Poem, 790)

In the poem, Dickinson shows her deep appreciation for nature. Nature, like our beloved mother, "impatiently" looks after all her children "with infinite affection and infinite care" as tenderly as we human beings do. All her children on the earth, no matter it is "the minutest cricket or the most unworthy flower", no matter it is "the feblest or the waywardest", will be treated equally by the gentlest mother ---nature. They can live a peaceful life in their own world without human intrusion. It has depicted for us "a partnership-based society that advances communication and mutual respect, pursues the development of life-sustaining rather than life-destroying technologies, and emphasizing relationship rather than hierarchies, linking rather than ranking"[4]. Emerson has said in Nature "everything that has life gives sign of satisfaction, and the cattle that lies on the ground seems to have great and tranquil thoughts." The idea of mutual acceptance and dependence rules out any possibility of conquest and exploitation which descend an authentic "care ethics", the guiding principle of ecofeminist, a branch theory of ecocriticism.

The western environmental ethics think the animals out of human world are also "the subject of life" like human beings and they also have the capacity of experiencing and apperceiving sweets or bitters of life. "Small eco-environment" originated with Charles Eton in 1920s. It refers to "the occupied room by the minor species in biotic community. Because of the high-specification during evolutionary processes, the species with different living performances own the chances of existence in the special environment" [5]. Therefore, a living thing lives neither for human beings' need nor for obstructing human beings but plays a role which its biological character and environmental character have decided. All the living things in nature are the existence of their own. Let's read the poem Further in summer than the Birds:

Further in summer than the Birds,

Pathetic from the Grass;

A minor Nation celebrated,

It's unobtrusive Mass.

No Ordinance be seen,

Yet a Druidic Difference,

Enhances Nature now. (Poem 1608)

From the poem, we can imagine a minor Nation: further in summer than the Birds, there is a "minor Nation" in the grass.
The Mass living in the minor Nation are "unobtrusive". The Mass celebrates. Dickinson unfolded us a nation different from human world, in which many Ordinance can be seen everywhere. The grass is the small eco-environment. The Mass living in the eco-environment exist regardless of human beings' interests. Human beings are just the bystanders. On the other poem A BIRD came down the walk, human being also performs the bystander's role. "A BIRD came down the walk". He bit an angle-worm in halves/ And ate the fellow, raw. /And then he drank a dew From a convenient grass, / And the hopped sidewise to the wall/ To let a beetle pass. But when I offered him a crumb, And he unroofed his feathers And rowed him softer home. In the poem, the bird just lives for himself but not for the interests of human beings which is extremely opposite to the human beings' human-centered and selfimportant idea. It is no doubt that Dickinson did express such an ecological consciousness: human beings is just a member of nature and coexist with other livings in nature.

Like Thoreau, Dickinson believed that people need to understand nature before they could begin to comprehend humanity because humanity was just a part of nature. Dickinson also went against the Church which was an extreme rarity of the time. Similar to many other that shared her beliefs she too did not think that a set religion was the way for salvation. Some keep the Sabbath going to Church;/ I keep it staying at home, /With a bobolike for a chorister, /With an orchard for a dome. According to this poem Emily clearly states that nature is her source of guidance and she has little need for the Church as an institution.

\section{The Soul Should Stand in Awe}

In 1920s, Albert Schweitzer, the famous German philosopher, put forward the parlance awe for life in his ecological moral thoughts. Awe here means when facing a kind of great and mysterious power, the feeling of awe or humility come about. According to his point of view, any life has his own inner value and deserves our respect and awe [6].

Dickinson said in poem 683 The soul should stand in awe. This idea is identical with one of the most important items of the modern ecological aesthetics: recovering of the unknown charm in part of nature. The unknown charm in part of nature refers to the natural phenomenon our forefather could not explain in the primitive times. Resulting from it, they imagined some existential beings and phenomenon in nature symbolized spirit and embodied the enlightenment of God. That is what is called animalism or in other words, everything in nature has soul. The whole world has life and soul, including humans and nonhumans, including animals, flowers, grasses and trees. Animalism laid foundation for human beings' respect and awe for nature.

In many poems, Dickinson expressed her awe for nature. While Dickinson were experiencing "storm", she felt "It sounded as if the streets were running," and "Awe was all we could feel" In poem 520 I STARTED early, took my dog, the poet wanted to take her dog to visit the sea but surprised to find the sea "would eat me up" like evil and wild beast and "he followed close behind" when "I" wanted to escape. In poem A narrow fellow in the grass, the poet took the snake as nature's 
people. But when she met it, she "Without a tighter breathing, / And zero at the bone." As Dickinson accepted and listened to what nature really is, awe is what she felt deeply, which is reflected in Poem 348, "I Dreaded the first robin so/... I dared not meet the daffodils, /for fear their yellow gown/Would pierce me with a fashion..."

The simple and mysterious nature is Dickinson's most familiar as well as the unfamiliar source of inspiration. Her inspection and guess for nature can be seen everywhere in her poems. In poem Nature is what we see, Dickinson spoke out a baffling nature: Nature is what we know /Yet have no art to say/ So impotent Our wisdom is/ To her Simplicity. (Poem: 668). Nature in Dickinson's eyes is the embodiment of over soul and knowledge as well, but "Our wisdom" is unable to understand the simple nature in our words, human beings just can follow the boundary and the room which the existential beings set up for themselves while appreciating the beautiful nature with heart, listening to it and praising it. Henry D. Thoreau shared the same ecological consciousness: Enjoy it, but not possess it.

Her poem The skies can't keep their secret is a case in point:

The skies can't keep their secret!

They tell it to the hills --

The hills just tell the orchards --

And they the daffodils!

A bird, by chance, that goes that way

Soft overheard the whole.

If I should bribe the little bird,

Who knows but she would tell?

I think I won't, however,

It's finer not to know;

If summer were an axiom,

What sorcery had snow?

So keep your secret, Father!

I would not, if I could,

Know what the sapphire fellows do,

In your new-fashioned world! (Poem 203)

The "skies", "the hill", "the orchards", "the daffodils" and "a bird" know the secret , and "I" am hovering over if "I should bribe the little bird" to get the secret . Finally, "I think I won't" "It's finer not to know". Nature is free and runs as its own rules. Human beings shouldn't interfere it or change it. Just it says "If summer were an axiom, What sorcery had snow?" Because nature is above and independent of human's will. Everything in nature is proceeding in regular and systematic order and isn't easy to be stop or changed.

The mystery and the unknown aspect of nature in Dickinson poems accounts she acknowledged the unknown charm in nature to some content. Her thought corresponds to Henry D.Thoreau: nature has its own significance far beyond what sense organs can grasp which science cannot also know its bounds. From point view of ecological moral thought, the poems which Dickinson described the nature's alienation and indifference as well as awe for nature demonstrated the idea of anti-anthropocentricism and it is can be seen that human beings is not the conqueror of nature and cannot possess, control and use the nature as its will.

\section{CONCLUSION}

With the closing reading, the author of this thesis finds that the ecological consciousness can be felt in Dickinson's nature poems which present us a harmonious relationship between humans and nature. In Dickinson's eye, nature is the harmonious coexistence of all things known by our senses and intuition, and a dwelling place for so many fascinating creatures, emotions. So many fascinating creatures or nonhumans also have their intrinsic value and life style like human beings, humans shouldn't interfere in their world but should live in harmony and equality with them. The harmonious nature is full of mystery which humans are hard to grasp and also increase the charm of nature. As a result, humans should stand in awe for nature, or stand in awe for life.

Dickinson's nature poems remind us of our dignity to protect the balance and integrity in nature, and then guide us to solve the ecological problems which threaten human life today. Searching for harmony both in physical world and spiritual world. Dickinson, the nature lover, is undoubtedly one of the forerunners of western ecological philosophies.

\section{REFERENCES}

[1] Worster, Donald. The Wealth of Nature: Environmental History and Ecological Imagination. New York: Oxford UP,1993.

[2] Yaoxin, Chang. American Literature History [M]. Tianjing:Nankai University Press ,2003:100.

[3] Heidegger, Martin. “...Poetically Man Dwells....” The Green Studies Reader: From Romanticism to Ecocriticism. Ed. Laurence Coupe .London: Routledge,2000: 90.

[4] Janson, Deborah. "In Search of Common Ground: An Ecofeminist Inquiry into Christa Wolf's Work.". Ecofeminist Literary Criticism: Theory ,Interpretation . Pedagogy. Eds.Greta Gaard and Patrick D.Murphy. Urbana : University of Illinois Press, 1998:173.

[5] Nash, Roderick Frazier. The Right of Nature [M]. Charlotesville and Londeon: The University Press of Virginia, 2000.

[6] Schweitzer, Albert Die Ehrfurcht Vor Dem Leben [M]. Shanghai:Shanghai Social Science Press,2002:19-20. 